\title{
Implantation of AtT-20 or Genetically Modified AtT-20/hENK Cells in Mouse Spinal Cord Induced Antinociception and Opioid Tolerance
}

\author{
Hope H. Wu, ${ }^{1}$ George L. Wilcox, ${ }^{1,2}$ and Steven C. McLoon ${ }^{2.3}$ \\ 'Department of Pharmacology, ${ }^{2}$ Graduate Program in Neuroscience, and ${ }^{3}$ Department of Cell Biology and Neuroanatomy, \\ University of Minnesota, Minneapolis, Minnesota 55455
}

\begin{abstract}
AtT-20 cells, which make and release $\beta$-endorphin, or AtT20/hENK cells, an AtT-20 cell line transfected with the human proenkephalin gene and secreting enkephalin as well as presumably $\beta$-endorphin, were implanted in mouse spinal subarachnoid space. Cell implants did not affect the basal response to thermal nociceptive stimuli. Administration of isoproterenol, believed to stimulate secretion from these cells, produced antinociception in groups receiving AtT-20 or AtT-20/hENK cell implants but not in control groups receiving no cells. The antinociceptive effect of isoproterenol was dose related and could be blocked by the opioid antagonist naloxone. Implantation of these cells offers a novel approach for the study of tolerance. Mice receiving AtT-20 cell implants developed tolerance to $\beta$-endorphin and the $\mu$-opioid agonist DAMGO, whereas mice receiving genetically modified AtT-20/hENK cell implants developed tolerance to the $\delta$-opioid agonist DPDPE. Genetically modified AtT-20/hENK cell implants, but not AtT-20 cell implants, reduced the development of acute morphine tolerance in the host mice. This finding is consistent with the suggestion that enkephalin alters development of opioid tolerance. These results suggest that opioid-releasing cells implanted around mouse spinal cord can produce antinociception and may provide an alternative therapy for chronic intractable pain.
\end{abstract}

IKey words: endorphin, enkephalin, neuronal cell line, pain, transplantation, tolerance]

The pharmacological control of chronic pain remains elusive (Bonica, 1990). It is well accepted that endogenously produced opioid peptides, such as $\beta$-endorphin and enkephalin, play an important role in reducing sensitivity to pain (Yaksh and Noucihed, 1985). When cxogenously administered at the spinal level, these opioid peptides produce profound antinociceptive effects in rodents (Yaksh et al., 1977; Yaksh and Henry, 1978; Yaksh, 1981; Hylden and Wilcox, 1983) and suppress pain in paticnts (Oyama ct al., 1980; Wcn et al., 1985). Although spinal

\footnotetext{
Received July 21, 1993; revised Dec. 27, 1993; accepted Feb. 8, 1994.

We thank Dr. R. P. Elde (University of Minnesota) for gifts of antisera to met enkephalin and of morphine, Dr. P. Y. Law (University of Minnesola) for a gift of ZK 62711. Dr. M. Martin (Roche Institute) for a gift of the AtT-20/hENK cells, and Dr. F. Porreca (University of Arizona) for gifts of $\beta$-funaltrexamine and ICI 174,864. We thank Multiple Peptide Systems for a gift of $\beta$-endorphin. We also thank Dr. C. V. Williams for her helpful advice. This research was supported by USPHS Grants DA-01933, DA-04274, and DA-00145 to G.L.W., and EY05371, EY-09537, and EY-07133 to S.C.M

Correspondence should be addressed to Dr. Steven C. McLoon, Department of Cell Biology and Neuroanatomy, University of Minnesota, 4-135 Jackson Hall 321 Church Street, Minneapolis, MN 55455.

Copyright (C) 1994 Society for Neuroscience $0270-6474 / 94 / 144806-09 \$ 05.00 / 0$
}

administration of opioids reduces total dosage requirements compared with systemic administration by targeting the drugs to an important site of action, the prolonged use of infusion catheters may be accompanied by problems such as occlusion, blockage, infection, and leakage (Laugner et al., 1985; Coombs, 1988; Hassenbusch et al., 1990; Onofrio and Yaksh, 1990; Plummer et al., 1991). Therefore, it is important to seek a means to circumvent these drawbacks in the control of chronic pain.

One possible approach to chronic opioid administration is to implant tissues that secrete opioid peptides around the spinal cord to reduce the spinal transmission of pain (Sagen et al., $1991 \mathrm{~b})$. One group has reported that spinal implantation of adrenal medullary tissuc produced measurable antinociception in rats (Sagen and Pappas, 1987; Sagen et al., 1990), decreased indications of pain in a rodent model of neuropathic pain (Hama and Sagen, 1993), and pain relief in terminal cancer patients (Sagen et al., 199lb). These adrenal medullary implants survived for at least 12 weeks and released both enkephalins (Sagen and Kemmler, 1989) and catecholamines (Sagen et al., 199 la) tonically or upon stimulation with nicotine. The risk of surgical complications associated with autologous tissue grafts, the limited availability of heterologous donor tissue, and the relatively low levels of secretion of pain-attenuating substances make an alternative to primary tissue grafts desirable.

Another possibility would be to implant a clonal cell line, that chronically secretes opioids, around the spinal cord. The AtT-20 cell line was originally derived from a mouse anterior pituitary tumor (Buonassisi et al., 1962) and secretes the opioid peptide $\beta$-endorphin (Allen et al.. 1978; Hook ct al., 1982). The genetically modified cell line AtT-20/hENK was developed from the AtT-20 cell line by introduction of a plasmid containing the entire human proenkephalin gene with 200 bases of 5 -flanking sequence and 2.66 kilobases (kb) of 3 '-flanking sequence (Comb et al., 1985). These cells express proenkephalin protein, which is cleaved to form free enkephalins (Comb et al., 1985). Genetically modified AtT-20/hENK cells presumably secrete $\beta$-endorphin as well. AtT-20 cells also possess $\beta_{2}$-adrenergic receptors, which would allow the $\beta$-adrenergic agonist isoproterenol to stimulate secretion from these cells after implantation (Reisine et al., 1983; Axelrod and Reisine, 1984). Thus, AtT-20 and At T-20/hENK cells hold potential for pharmacological manipulation of their release of opioids after implantation. The present study characterized the analgesic or antinociceptive effectiveness of these two cell lines implanted around the spinal cord of mice and stimulated by a $\beta$-adrenergic agonist.

Chronic implantation of opioid-secreting cells also offers a novel approach for the study of tolerance associated with longterm opioid administration. The development of tolerance re- 
duces the effectiveness of drug therapies and requires escalated doses that can contribute to opioid side effects. Since primates receiving chronic intrathecal (i.t.) administration of $\beta$-endorphin developed tolerance to it (Yaksh et al., 1982), it was expected that spinal implantation of AtT-20 cells secreting $\beta$-endorphin would produce opioid tolerance as well. Furthermore, since the antinociceptive effect of enkephalins is mediated mainly through $\delta$-opioid receptors (Yaksh and Noueihed, 1985), spinal implantation of AtT-20/hENK cells secreting enkephalins tonically should also produce tolerance at $\delta$-opioid receptors. The induction of opioid tolerance following cell implantation would confirm that the implanted cells tonically release opioids. Because of the quick degradation of enkephalins in the ncrvous system (Yaksh et al., 1977; Yaksh and Noueihed, 1985), it is generally difficult to study the development of enkephalin tolerance or the effects of enkephalin on the development of tolerance to other opioids. Implantation of cells that tonically secrete enkephalins offers another method to continuously supply enkephalins. It has been suggested that met-enkephalin can alter the development of tolerance to the opiate morphine (Graf et al., 1979), although technical aspects of enkephalin delivery limited the strength of this conclusion and permitted some dispute (Lee et al., 1980). To help resolve this issue, the present study examined development of tolerance to morphine in animals with chronic implantation of AtT $-20 /$ hENK cells.

The results of this study showed that intrathecally implanted At $\mathrm{I}-20$ or At $\mathrm{I}-20 / \mathrm{hENK}$ cells had an antinociceptive effect when secretion from the cells was stimulated by isoproterenol. This isoprotcrcnol-induced antinociception was blocked by the opioid antagonist naloxone, suggesting that this antinociception was induced by opioids released from the cell implants. Mice receiving cell implants developed tolerance to opioids, confirming that these cells tonically released opioids. AtT $-20 / \mathrm{hENK}$ cell implants reduced the development of acute morphine tolerance, which indicates that enkephalins can modulate the development of morphine tolerance.

Preliminary results have been reported previously in abstract form (Wu et al., 1992).

\section{Materials and Methods}

Cell culture and preparation for implantation. AtT-20 cells (Buonassisi et al., 1962) and AtT-20/hENK cells (Comb et al., 1985, a gift from Dr. M. Martin) were grown in Dulbecco's modified Eagle's medium (DMEM) containing 12\% horse serum and 3\% fetal calf serum under $10 \% \mathrm{CO}$ and $90 \%$ air at $37^{\circ} \mathrm{C}$. AtT $-20 / \mathrm{hENK}$ cells were detached from the culture flasks with trypsin/EDTA medium. All cells were removed from the culture flasks, centrifuged at $500 \times \mathrm{g}$ for $3 \mathrm{~min}$, resuspended in Hanks' buffer ( $\mathrm{pH} 7.4$ ), and counted with a hemocytometer. The cells were again centrifuged and resuspended in Hanks' buffer at the desired concentrations for intrathecal administration to recipient animals.

Animals and cell implantation. Recipients were male ICR mice weighing 20-24 gm (Harlan Sprague-Dawley, Madison, WI). Animals were maintained on a $12 / 12 \mathrm{hr}$ light/dark cycle with chow and water available ad libitum. Five microliters of Hanks' buffer solution containing $10^{3}$ cells was injected into mouse lumbar subarachnoid space by lumbar puncture using a 27 gauge needle (Hylden and Wilcox, 1980; Wilcox, 1988). Control animals received an injection of the same volume of Hanks' buffer solution.

Drugs. Isoproterenol (7-30 nmol; Aldrich Chemical Company, Inc., Milwaukee, WI) was prepared in physiological saline containing the cAMP phosphodiesterase inhibitor ZK 62711 (Schwable et al., 1976; a gift from Dr. P. Y. Law). ZK 62711 was dissolved in absolute ethanol $(30 \mathrm{mg} / \mathrm{ml})$ and then diluted with physiological saline to a final ethanol concentration of $0.6 \%$. Naloxone hydrochloride $(3 \mathrm{nmol}$; E.I. Dupont Co., Garden City, NJ), morphine (3-30 nmol; a gift from Dr. R. P. Elde), $\beta$-endorphin (0.01-3 nmol; a gift from Multiple Peptide Systems,
San Diego, CA), DAMGO (0.003-0.07 nmol; Sigma Chemical Company, St. Louis, MO), DPDPE (3-100 nmol; Bachem Inc., Torrence, CA), $\beta$-funaltrexamine ( $\beta$-FNA; $0.05 \mathrm{nmol}$; a gift from Dr. F. Porreca), and ICI 174,864 (10 $\mu \mathrm{g}$; a gift from Dr. F. Porreca) were prepared in physiological saline. The drugs were given by intrathecal injection ( 5 $\mu$ l) using a 30 gauge needle. The drug studies were limited to 1 month after cell implantation because the larger size of the mice after this point made intrathecal drug injections difficult.

Antinociceptive testing. Two standard nociceptive tests. tail flick and hot plate, were used sequentially before and after cell implantation or drug administration. In the tail flick test, the tail of an animal was immersed in a hot water bath $\left(53^{\circ} \mathrm{C}\right.$ or $\left.55^{\circ} \mathrm{C}\right)$. The $53^{\circ} \mathrm{C}$ hot water tail flick test, instead of the $55^{\circ} \mathrm{C}$ hol water lail flick test, was used in mice receiving isoproterenol (intrathecally) to detect opioid antinociception induced by cell implants because it was observed that opioid efficacy was higher in the lower temperature hot water tail flick test (Jiang et al., 1990; Kitto and Wilcox, unpublished data). The $55^{\circ} \mathrm{C}$ hot water tail flick test was used in mice receiving all the other drugs because they were fully effective in this test (Heyman et al., 1989). The time required for an animal to move its tail away from the hot water bath was measured (Janssen et al., 1963). The baseline response time for the tail flick tests was $2.9 \pm 0.2 \mathrm{sec}$ at $53^{\circ} \mathrm{C}$, and $2.3 \pm 0.2 \mathrm{sec}$ at $55^{\circ} \mathrm{C}$. The cutoff time was set at $10 \mathrm{sec}$. In the hot plate test the temperature of an aluminum plate $(20 \times 35 \mathrm{~cm})$ in a clear plastic enclosure $(34 \mathrm{~cm}$ high) was maintained at $55^{\circ} \mathrm{C}$ by circulating hot water (Woolfe and MacDonald, 1944). Each subject was placed on the hot plate and the latency to jump or lick its hind paw was measured. The baseline response time in the absence of treatment was $17.6 \pm 1.4 \mathrm{sec}$. The cutoff time was set at 40 sec. These maximum cutoff latencies were set to avoid tissue damage and were determined to be more than three standard deviations above the control mean for several pooled groups of animals. The percentage maximum possible effect (MPE) was determined in the usual way: $\%$ $\mathrm{MPE}=$ (postdrug latency - predrug latency)/(cutoff - predrug latency) $\times 100 \%$.

Acute morphine tolerance test. Mice were pretreated with an intrathecal injection $(5 \mu \mathrm{l})$ of morphine $(20 \mathrm{nmol})$ or saline. Six hours later, the tail flick $\left(55^{\circ} \mathrm{C}\right)$ test was performed before and 10 min after receiving morphine $(10 \mathrm{nmol})$. The response latency in animals pretreated with morphine was compared to those pretreated with saline.

Histology. A histological analysis of implant survival was performed in mice following the nociceptive tests. Mice were antesthetized with ether and perfused with $4 \%$ paraformaldehyde in $0.1 \mathrm{M}$ phosphate buffer (pH 7.4). The spinal cords were removed and postfixed $2 \mathrm{hr}$ at $4^{\circ} \mathrm{C}$, then placed in $20 \%$ sucrose $/ 0.1 \mathrm{M}$ phosphate buffer overnight at $4^{\circ} \mathrm{C}$. The spinal cords were embedded in tragacanth gum and stored at $-70^{\circ} \mathrm{C}$ until sectioning. Spinal cords were sectioned on a cryostat at $12 \mu \mathrm{m}$. Selected sections were stained with cresyl violet. Adjacent sections were incubated first in rabbit anti-met-enkephalin antisera (a gift from Dr. R. P. Elde) at 1:100 in PBS (Micevych and Flde, 1980) and then in goat anti-rabbit IgG antibody conjugated to fluorescein isothiocyanate (Jackson Immunoresearch Laboratories, Inc., West Grove, PA) at 1:500 in PBS. The sections were examined and photographed with a microscope under transmitted or epifluorescence illumination.

Statistical analvsis. Statistical analyses were performed using STATVIEw II analysis of variance (ANOVA) followed by Fisher PLSD test for multiple post hoc comparisons among the groups. Differences were considered to be significant if $p<0.05$. The $\mathrm{ED}_{50}$ values and $95 \%$ confidence intervals of drugs in $\mathrm{nmol} / \mathrm{mouse}$ were calculated by using the graded dose-response curve method of Tallarida and Murray (1987). $\mathrm{ED}_{i n}$ values were considered to be significantly different when $95 \%$ confidence intervals did not overlap between the groups.

\section{Results}

Antinociceptive effect of AtT-20 and genetically modified At $T-20 / \mathrm{hENK}$ cell implants

Three groups of mice received an intrathecal injection of AtT20 cells, AtT-20/hENK cells, or Hanks' buffer. The mice were tested in the tail flick and hot plate tests $1 \mathrm{~d}$ before and 1, 3, 5, 7 , and $21 \mathrm{~d}$ after implantation. Neither AtT-20 nor AtT-20/ hENK cell implants resulted in a detectable change in the basal tail flick or the hot plate response latencies (data not shown). This may be due to low sensitivity of these behavioral tests or 
A

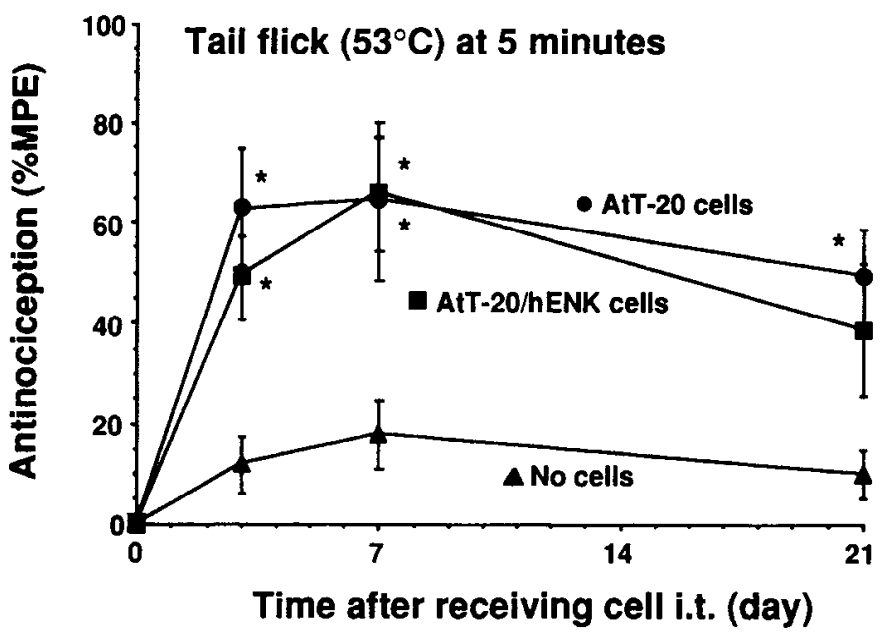

B

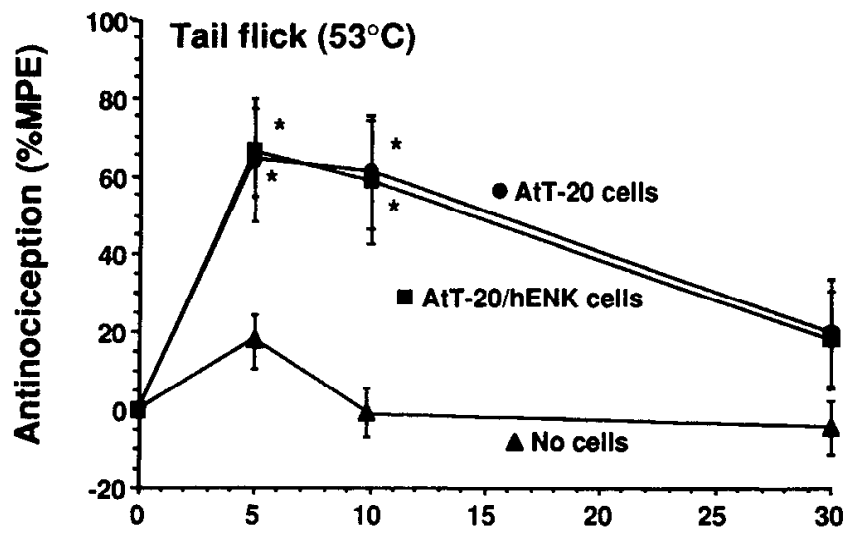

Time after $30 \mathrm{nmol}$ isoproterenol i.t. (min)

Figure 1. Antinociceptive effect of the $\beta$-adrenergic agonist isoproterenol ( $30 \mathrm{nmol}$, i.t.) together with the cAMP phosphodiesterase inhibitor ZK $62711(1.0 \mu \mathrm{g}$, i.t. $)$ in mice receiving AtT-20 or AtT-20/hENK cells $\left(10^{5}\right.$ cells, i.t.) in the tail flick test. $A, \mathrm{~A}$ two-factor repeated-measures ANOVA indicated that the antinociceptive effect of isoproterenol was statistically significant $\left(F_{2,}=13, p<0.001\right)$. Significant post hoc comparisons are indicated by * $(p<0.05)$. The AtT-20 cell-implanted group and the AtT-20/hENK cell-implanted group showed more antinociception than the control group. $B$, The time course of the isoproterenol effect in mice $7 \mathrm{~d}$ after receiving AtT-20 or AtT-20/hENK cells $\left(10^{5}\right.$ cells, i.t.). A two-factor repeated-measures ANOVA indicated that the antinociceptive effect of isoproterenol was statistically significant $\left(F_{2,21}\right.$ $=7, p<0.005)$. Significant post hoc comparisons are indicated by * $(p$ $<0.05)$. The AtT-20 cell-implanted group and the AtT-20/hENK cellimplanted group showed more antinociception than the control group. Each point represents the mean \pm SEM (eight mice in each group)

to low levels of spontaneous secretion of opioid by these cells (Allen et al., 1978; Hook et al., 1982; Comb et al., 1985).

The $\beta$-adrenergic agonist isoproterenol was used in an attempt to increase secretion from the cell implants. Previous work showed that isoproterenol administered in normal rodent spinal cord lacks antinociceptive effects (Yaksh, 1985; Nagasaka and Yaksh, 1990). Thus, any antinociception induced by isoproter- enol would most likely result from stimulation of opioid secretion from the implanted cells. The $\beta$-adrenergic agonist isoproterenol, injected intrathecally in cell-implanted mice, elevated both tail flick and hot plate response latencics 5 and $10 \mathrm{~min}$ after injection but was without effect in mice receiving no implants (Fig. $1 A, B$ ). The antinociceptive effect of isoproterenol in mice receiving AtT-20 or AtT-20/hENK cell implants was dose related in both tail flick (Fig. $2 A$ ) and hot plate (Fig. $2 B$ ) tests, and was completely blocked by intrathecal coadministration of $3 \mathrm{nmol}$ of the opioid antagonist naloxone, a dose that had no effect on its own in any of the three groups. The antinociceptive effect of isoproterenol appeared the same in mice receiving genetically modified AtT $-20 / \mathrm{hENK}$ and AtT -20 cell implants. It was unclear from this result whether enkephalin was involved in the antinociceptive effect associated with the AtT-20/hENK cell implants.

The contribution to the antinociceptive effect of enkephalin and $\beta$-endorphin secreted from the cell implants was determined using selective $\delta$ - and $\mu$-opioid receptor antagonists. Antinociception produced by enkephalin is mediated mostly through $\delta$-opioid receptors, while that produced by $\beta$-endorphin is mediated mostly through $\mu$ opioid receptors (Yaksh and Noueihed, 1985; Suh and Tseng, 1988). Mice receiving either AtT-20 or AtT-20/hENK cell implants were given the $\mu$-opioid receptor antagonist $\beta$-FNA $(0.05 \mathrm{nmol}$, i.t.) $2 \mathrm{~d}$ after implantation. This dose of $\beta$-FNA selectively blocks $\mu$-opioid receptors while having littlc effect on $\delta$-opioid receptors in mice $24 \mathrm{hr}$ after administration (Suh and Tseng, 1990). Twenty-four hours after $\beta$-FNA treatment, $30 \mathrm{nmol}$ of isoproterenol was given by intrathecal injection, and the mice were tested for a nociceptive response. The antinociceptive effect of isoproterenol in the tail flick test was blocked by pretreatment with $\beta$-FNA in mice receiving the At T -20 cell implants but not in mice receiving the genetically modified AtT-20/hENK cell implants (Fig. 3A). When the $\delta$-opioid antagonist ICI 174,864 (10 $\mu \mathrm{g}$, i.t.) was given to mice pretreated with $\beta$-FNA, the antinociceptive effect of isoproterenol in the tail flick test was blocked completely in mice receiving either AtT-20 or AtT-20/hENK cell implants (Fig. 3B). However, ICI 174,864 (10 $\mu \mathrm{g}$, i.t.) alone did not block isoproterenolinduced antinociception in mice receiving either type of cell implants (data not shown). Thus, the effect of AtT-20 cell implants, which secrete only $\beta$-endorphin, could be blocked by blocking only $\mu$-opioid receptors. Elimination of the effect of AtT-20/hENK cell implants, which apparently secrete both $\beta$-endorphin and enkephalin, required both $\mu$ - and $\delta$-opioid receptor blockers.

\section{Tolerance associated with AtT-20 and genetically modified 4t $T$-20/hENK cell implants}

Opioid tolerance in mice receiving cell implants was tested by administering several doses of opioid agonists to mice $7 \mathrm{~d}$ after cell implantation. Mice receiving AtT-20 cell implants showed tolerance to $\beta$-endorphin and the selective $\mu$-opioid agonist DAMGO, whereas mice receiving AtT-20/hENK cell implants showed tolerance to the selective $\delta$-opioid agonist DPDPE. $\beta$-endorphin was sixfold less potent in the tail flick test (Fig. $4 A$ ), and 21 -fold less potent in the hot plate test in mice receiving At $\mathrm{T}-20$ cell implants than in control mice in the hot plate test (Fig. $4 B$ ). No such difference in $\beta$-endorphin potency was evident in AtT-20/hENK cell-implanted mice (Fig. $4 A, B$ ). The selective $\mu$-opioid agonist DAMGO was threefold less potent in mice receiving At $\mathrm{T}-20$ cell implants than in control mice in the 
A

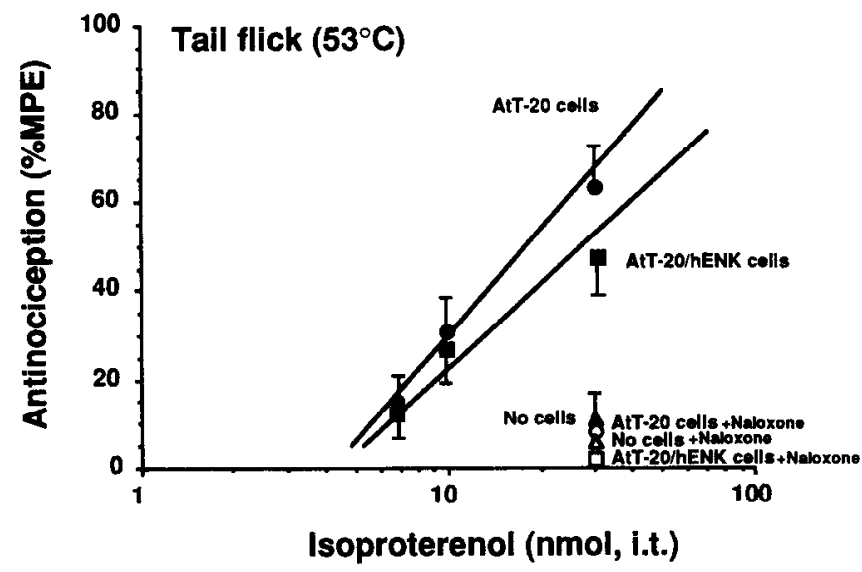

B

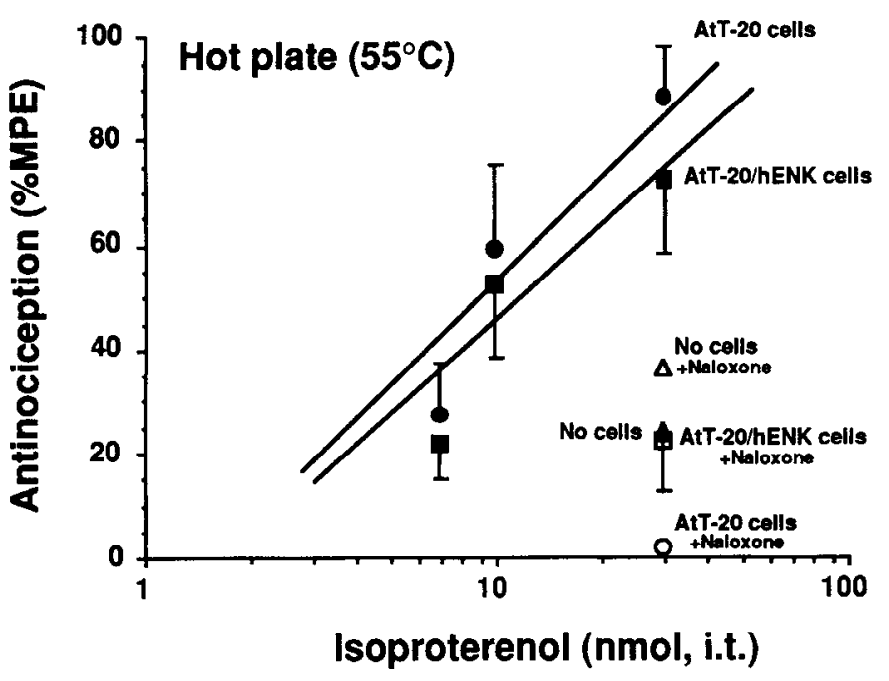

Figure 2. Dose-related isoproterenol-induced antinociception in mice $3 \mathrm{~d}$ after receiving AtT-20 or AtT $-20 / \mathrm{hENK}$ cells $\left(10^{\text {s }}\right.$ cells, i.t.). This effect was blocked by the opioid antagonist naloxone $(3 \mathrm{nmol}$, i.t.) in the tail flick $(A)$ and hot plate $(B)$ tests. Each point represents the mean \pm SEM (eight mice in each group).

tail flick test (Fig. 4C); no such difference was evident in AtT20/hENK cell-implanted mice (Fig. 4C). Furthermore, the selective $\delta$-opioid agonist DPDPE was fourfold less potent in mice receiving the genetically modified AtT-20/hENK cell implants than in control mice in the tail flick test (Fig. 4D); no such difference was evident in AtT-20 cell-implanted mice (Fig. 4D). No differences in DAMGO or DPDPE potency were evident between cell-implanted mice and control mice in the hot plate test (data not shown).

Mice receiving cell implants were also tested for development of opiate tolerance. Mice receiving AtT-20 cell implants and mice receiving no cell implants developed acute morphine tolerance $6 \mathrm{hr}$ after a $20 \mathrm{nmol}$ intrathecal dose of morphine; that is, $10 \mathrm{nmol}$ of morphine produced less antinociception in these mice, when compared with mice receiving $6 \mathrm{hr}$ pretreatment with saline (Fig. 5). The group receiving AtT-20/hENK cell
A

(B-FNA 0.05 nmol i.t. -24 hour)

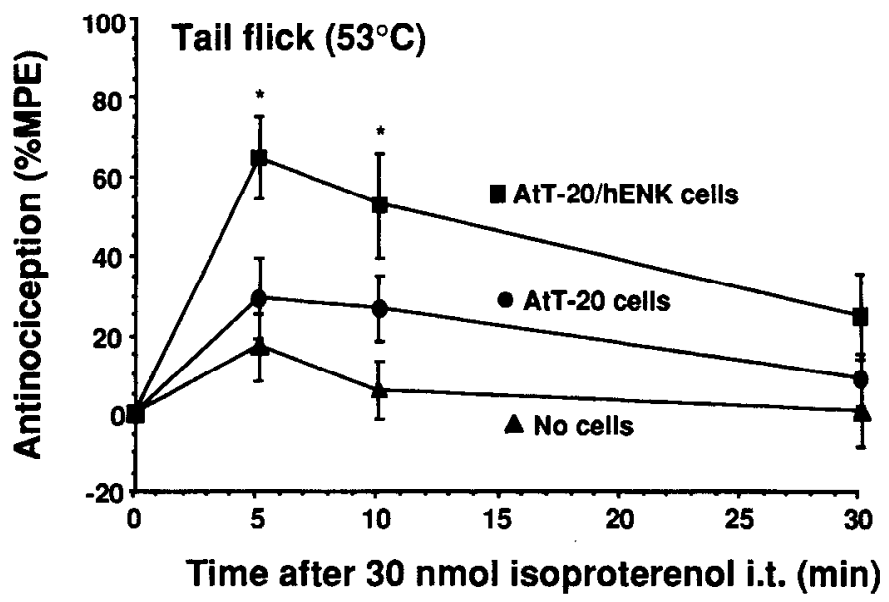

B

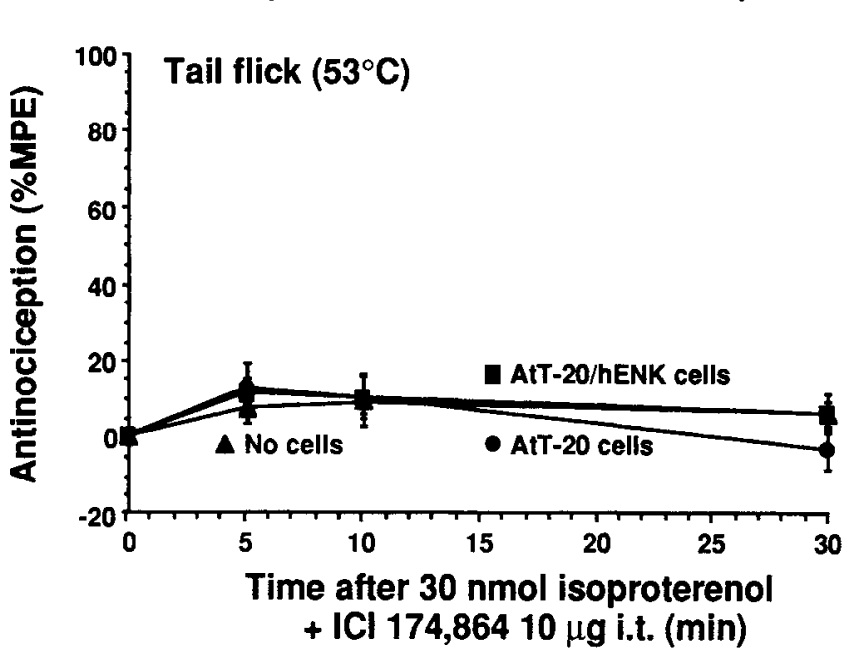

Figure 3. A, Antinociceptive effect of isoproterenol ( $30 \mathrm{nmol}$, i.t.) in mice $3 \mathrm{~d}$ after implantation of AtT-20 cells $\left(10^{5}\right.$ cells, i.t.) was blocked by a $24 \mathrm{hr}$ pretreatment of the selective $\mu$-opioid antagonist $\beta$-FNA $(0.05 \mathrm{nmol}$, i.t. $)$ in the tail flick test. The antinociceptive effect of isoproterenol persisted in mice $3 \mathrm{~d}$ after implantation of AtT-20/hENK cells $\left(10^{5}\right.$ cells, i.t.) and $24 \mathrm{hr}$ after pretreatment with $\beta$-FNA. A twofactor repeated-measures ANOVA indicated that the antinociceptive effect of isoproterenol was statistically significant $\left(F_{2_{2}}=8, p<0.005\right)$. Significant post hoc comparisons are indicated by ${ }^{*}(p<0.05)$. Each point represents the mean \pm SEM (nine mice in each group). $B$, Antinociceptive effect of isoproterenol ( 30 mmol, i.t.) in mice $3 \mathrm{~d}$ after implantation of AtT-20 or AtT-20/hENK cells $\left(10^{5}\right.$ cells, i.t.). This effect was blocked by the $\delta$-opioid antagonist ICI $174,864(10 \mu$ g, i.t. $) 24 \mathrm{hr}$ after pretreatment with $\beta$-FNA. Each point represents the mean \pm SEM (nine mice in each group).

implants, on the other hand, did not appear to develop tolerance; that is, morphine's effect was not diminished $6 \mathrm{hr}$ after $20 \mathrm{nmol}$ of morphine intrathecally (Fig. 5). A dose-response study confirmed this. Morphine was threefold less potent in mice pretreated $6 \mathrm{hr}$ earlier with an injection of morphine $(20 \mathrm{nmol}$, i.t. $)$ compared with saline-pretreated mice. No such tolerance was 
A

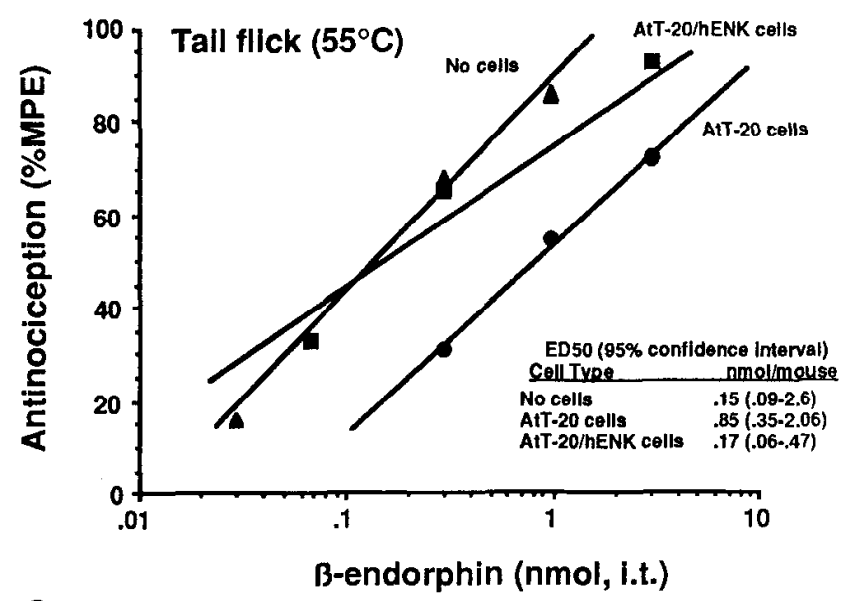

C

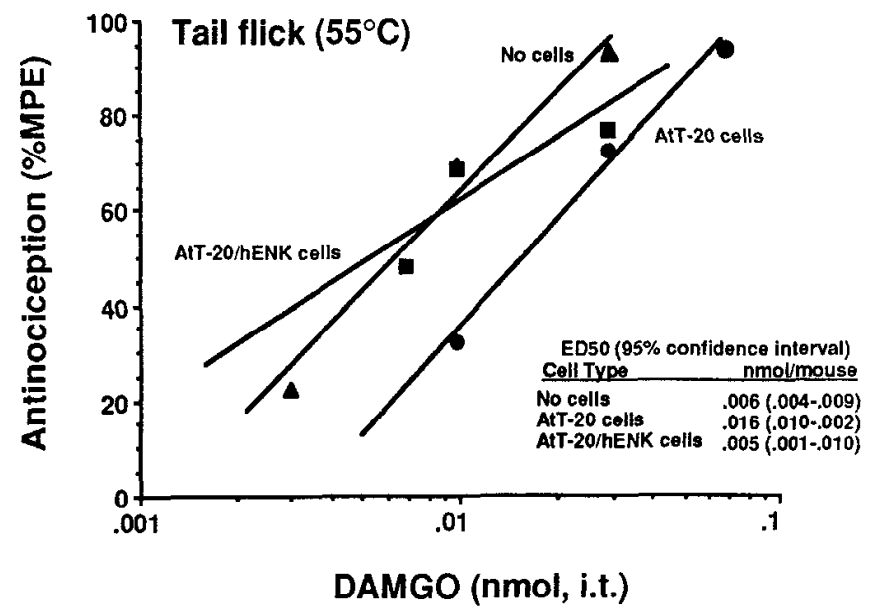

B

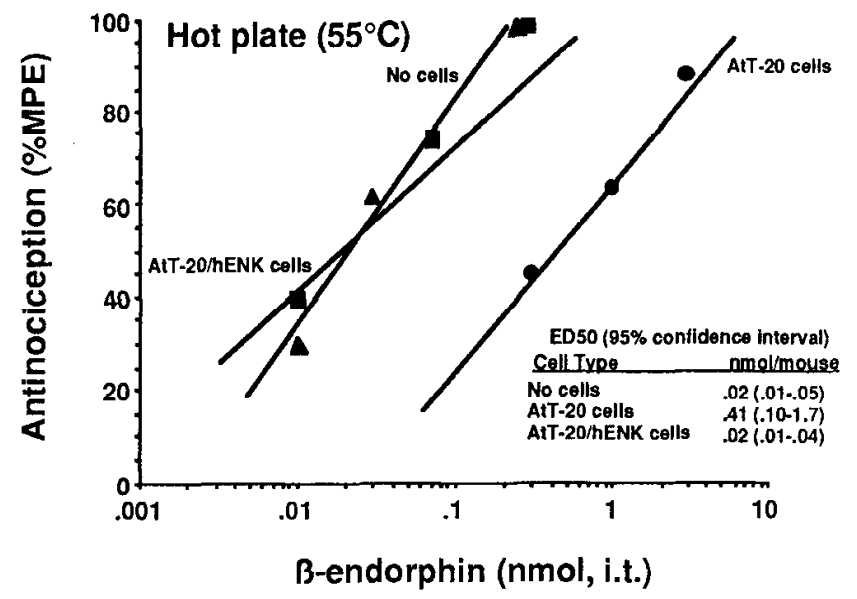

D

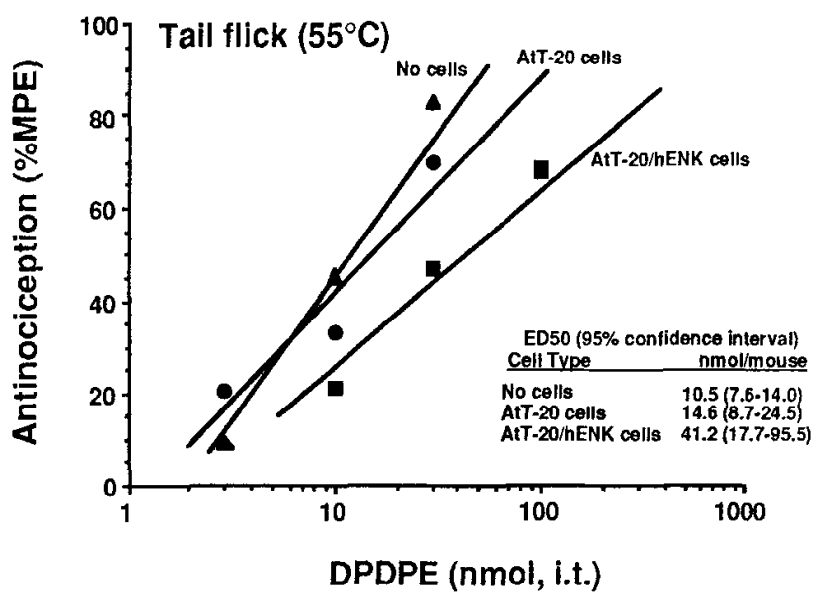

Figure 4. $\beta$-endorphin $(A, B), \mathrm{D} \wedge \mathrm{MGO}(C)$, and DPDPE $(D)$ dose-response curves after intrathecal administration in mice $7 \mathrm{~d}$ after implantation

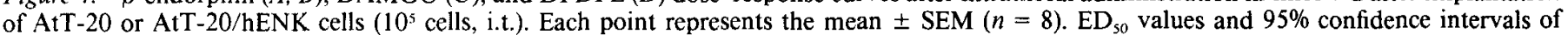
isoproterenol in $\mathrm{nmol} / \mathrm{mouse}$ were calculated using the graded dose-response curve method of Tallarida and Murray as described in Materials and Methods.

evident in mice receiving genetically modified AtT-20/hENK cell implants pretreated with $20 \mathrm{nmol}$ morphine intrathecally, when compared with saline-pretreated mice (Table 1). Thus, the release of enkephalin from the AtT-20/hENK cell implants appeared to reduce development of acute morphine tolerance.

\section{Histological examination of implanted cells}

Histological examination revealed clumps of round cells surrounding the spinal cord of mice receiving AtT-20 and AtT-20/ hENK cell implants. These cells were present in animals at least 1 month following implantation, the oldest age examined. These anomalous clumps of cells were not seen around the spinal cord of control mice, which did not receive cell implants. Immunohistochemical processing for met-enkephalin resulted in staining of these cells in animals that received the AtT-20/hENK cell implants (Fig. 6). No staining was observed in the cells surrounding the cord in mice with the AtT-20 cell implants. Normal staining of endogenous met-enkephalin was present in the dorsal horn of all three groups of animals.

\section{General health of host animals}

Mice receiving AtT-20 or AtT-20/hENK cell implants appeared healthy during the period of the experiments. The weight and motor ability of animals was monitored for 5 weeks after implantation. No significant difference was found in the body weight between the AtT-20 cell implantation group, At l -20/hENK cell implantation group, and the control group (Fig. 7). About 10\% of the micc receiving AtT-20/hENK cell implants developed hind limb paralysis during the third week following cell implantation. The remaining mice survived and appeared healthy during a 3 month period of intermittent observation.

\section{Discussion}

AtT-20 cells, which produce $\beta$-endorphin (Allen et al., 1978; Hook et al., 1982), or AtT-20/hENK cells, which were genetically modified to produce enkephalin as well (Combet al., 1985), were implanted around the mouse spinal cord and shown to produce antinociception in the host animals. This antinocicep- 


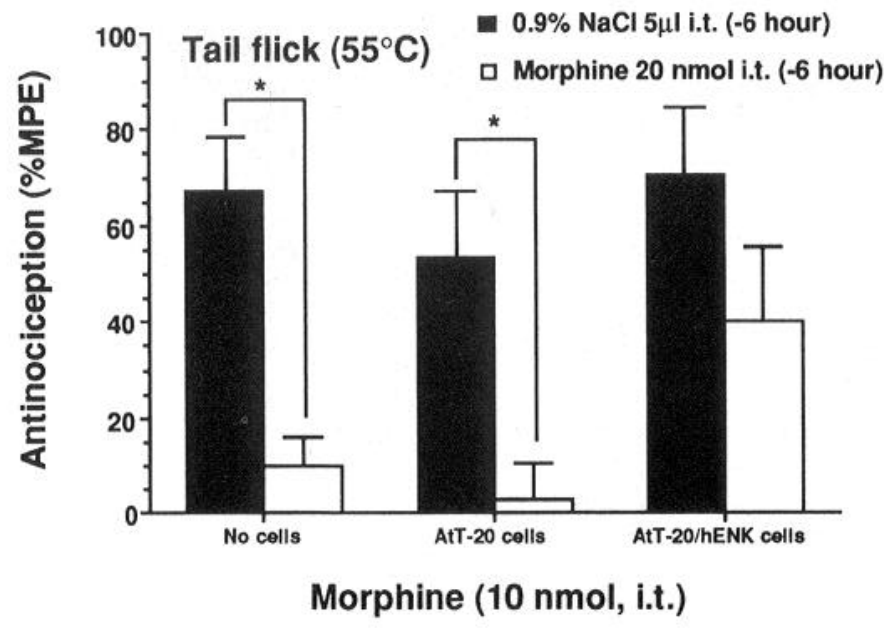

Figure 5. Antinociceptive effect of morphine $(10 \mathrm{nmol}$, i.t.) in mice 7 d after implantation of AtT-20 or AtT-20/hENK cells ( $10^{5}$ cells, i.t.) and $6 \mathrm{hr}$ after pretreatment with morphine ( $20 \mathrm{nmol}$, i.t.) or saline (5 $\mu$ l, i.t.). A one-factor ANOVA indicated that morphine-induced antinociception was statistically significant $\left(F_{\mathrm{S}_{42}}=6, p<0.001\right)$. The AtT20 cell-implanted group and the control group showed less morphineinduced antinociception $6 \mathrm{hr}$ after pretreatment with morphine (20 $\mathrm{nmol}$, i.t.) than $6 \mathrm{hr}$ after pretreatment with saline $(5 \mu$ l, i.t.). Morphineinduced antinociception was not significantly reduced in the AtT-20/ hENK cell-implanted group. Significant post hoc comparisons are indicated by * $(p<0.05)$. Each point represents the mean \pm SEM (eight mice in each group).

tive effect was detectable with standard tail flick and hot plate nociceptive tests only if the animals were treated intrathecally with isoproterenol. Control animals, which lacked cell implants, did not exhibit antinociception in response to this drug.

Baseline tail flick and hot plate latencies were not changed by the cell implants. A similar observation was made with adrenal medullary chromaffin cell implants (Sagen and Pappas, 1987). Nicotine stimulated transmitter release from adrenal medullary chromaffin cell implants and produced antinociception in the
Table 1. Mice receiving AtT-20/hENK cell implants did not develop tolerance $6 \mathrm{hr}$ after a $20 \mathrm{nmol}$ intrathecal dose of morphine

\begin{tabular}{llc} 
Cell type & Treatment & $\begin{array}{l}\mathrm{ED}_{50}(95 \% \\
\text { confidence } \\
\text { interval), } \\
\text { nmol/mouse }\end{array}$ \\
\hline No cells & Saline, $5 \mu \mathrm{l}$ & $7.7(6-11)$ \\
AtT-20/hENK cells & Morphine, $20 \mathrm{nmol}$ & $22.4(17-29)$ \\
& Saline, $5 \mu \mathrm{l}$ & $4.4(1-14)$ \\
& Morphine, $20 \mathrm{nmol}$ & $8.6(5-15)$
\end{tabular}

$\mathrm{ED}_{30}$ values and $95 \%$ confidence intervals of morphine (nmol/mouse, i.t.) in mice $7 \mathrm{~d}$ after implantation of AtT-20/hENK cells ( $10^{5}$ cells, i.t.) and $6 \mathrm{hr}$ after pretreatment with morphine ( $20 \mathrm{nmol}$, i.t.) or saline $(5 \mu$ l, i.t.). Acute tolerance was apparent in the control group but not in the AtT-20/hENK cell-implanted group ( 24 mice in each group).

host rats. In the present study, isoproterenol, which can stimulate opioid secretion from AtT-20 cells in vitro (Reisine et al., 1983; Axelrod and Reisine, 1984), was required to induce detectable antinociception in AtT-20 and AtT-20/hENK cell-implanted mice. The lack of detectable antinociception after spinal implantation of these cells without isoproterenol stimulation may have been due to low levels of spontaneous secretion of opioid by these cells (Allen et al., 1978; Hook et al., 1982; Comb et al., 1985). In contrast to animal studies, heterologous grafts of adrenal medullary cells in human spinal subarachnoid space of cancer patients did reduce pain (Sagen et al., 1991b). This result suggests that adrenal chromaffin cells, and possibly AtT20 and AtT-20/hENK cells, tonically release sufficient transmitter to decrease pain perception, but that the behavioral tests used lack the sensitivity to detect the effect.

The antinociceptive effect resulting from isoproterenol injection in mice receiving AtT-20 or AtT-20/hENK cell implants most likely resulted from opioids secreted from the implanted cells because it was blocked by the opioid antagonist naloxone. Since previous studies have shown that these cell lines produce

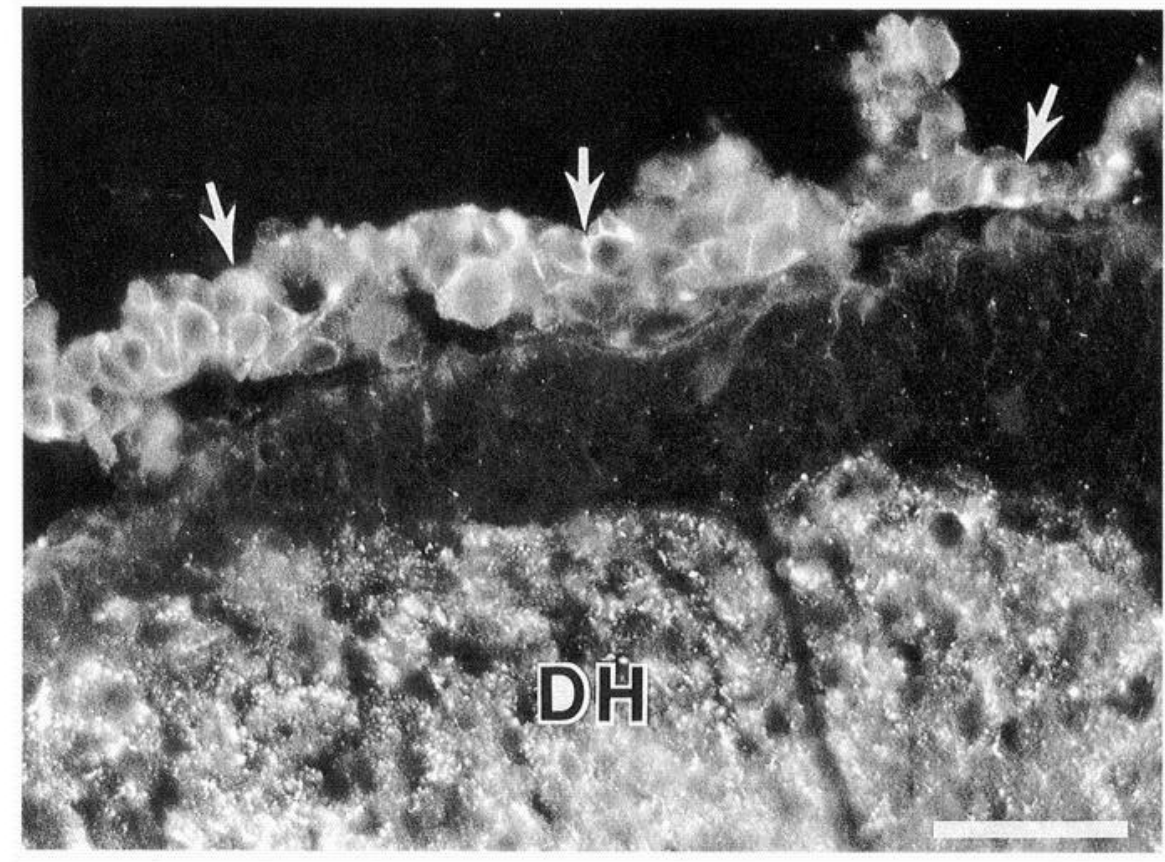

Figure 6. Photomicrograph of metenkephalin immunohistochemistry of AtT-20/hENK cells implanted around mouse spinal cord. Immunofluorescence staining is apparent within the implanted cells (arrows). Normal endogenous staining for met-enkephalin is also present in the dorsal horn $(D H)$. Scale bar, $50 \mu \mathrm{m}$. 


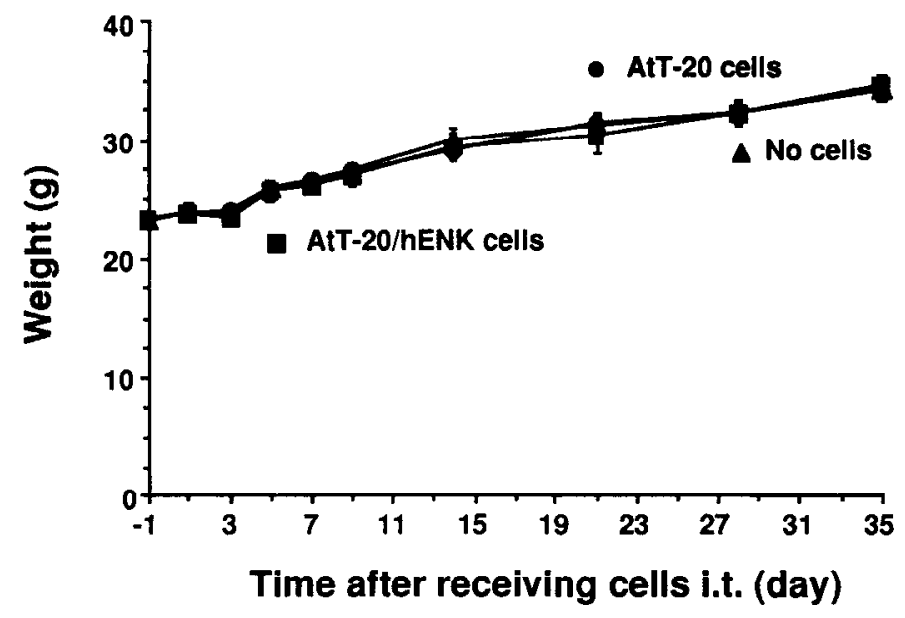

Figure 7. Body weight of mice receiving implants. Mice receiving AtT20 or At $\mathrm{T}-20 / \mathrm{hENK}$ cells $\left(10^{5}\right.$ cells, i.t. $)$ gained weight at the same rate as controls. Each point represents the mean \pm SEM (10 mice in each group).

and release opioids (Allen et al., 1978; Hook et al., 1982; Comb et al., 1985), and since isoproterenol has no antinociceptive effect in animals without the cell implants, it is reasonable to suggest that this opioid-mediated antinociception resulted from opioid peptides released from the implanted cells.

The AtT-20 cell implants appeared to act through the release of $\beta$-endorphin, while the At T-20/hENK cell implants appeared to act through the release of $\beta$-endorphin and enkephalin. It has been shown that the spinal antinociceptive effect of exogenously administered $\beta$-endorphin is mediated mainly by $\mu$-opioid receptors and the antinociceptive effect of enkephalin is mediated by $\delta$-opioid receptors (see review by Yaksh and Noueihed, 1985). In the present study, the antinociceptive effect of the AtT-20 cell implants was blocked by a $\mu$-opioid receptor blocker alone. The antinociceptive effect of AtT-20/hENK cell implants could not be blocked by either a $\mu$ - or $\delta$-opioid receptor blocker alone but required coadministration of the two. Thus, both the $\beta$-endorphin and enkephalin released by the AtT-20/hENK cells appeared to be active in the antinociceptive effect of these cells.

It was expected that the AtT-20/hENK cell implants, releasing both opioid peptides, would have a greater antinociceptive effect than the AtT-20 cell implants, which release only $\beta$-endorphin. A synergistic interaction is known to exist between the $\mu$ - and $\delta$-opioid receptors (Vaught and Takemori, 1979; Hylden and Wilcox, 1983). In the present study, the antinociceptive effect of isoproterenol treatment appeared equal in mice receiving AtT-20 or AtT-20/hENK cell implants. Although the reason for this is not clear, the present results agree with a previous observation showing that enkephalins had no effect on $\beta$-endorphin-induced analgesia (Chapmen et al., 1980). $\beta$-Endorphin has been shown to have a greater antinociceptive effect in the tail flick test than enkephalin when administered intrathecally to rats (Yaksh, 1981). It is likely that the larger antinociceptive effect of $\beta$-endorphin secreted by the AtT-20/hENK cells overshadowed a smaller effect of enkephalin; therefore, the behavioral assays may not have been sufficiently sensitive to detect the additional effect of the enkephalin. On the other hand, the synergistic interaction may depend on the opioid peptides involved. Leu-enkephalin potentiates the antinociceptive effect of morphine (Vaught and Takemori, 1979; Lee et al., 1980) while met-enkephalin decreases this effect (Vaught and Takemori, 1979; Chapmen et al., 1980; Lee et al., 1980). Since AtT-20/ hENK cells most likely secrete both leu-enkephalin and metenkephalin, the potentiating effect of one peptide may be offset by the antagonistic effect of the other.

Implantation of opioid-releasing cells offers a novel approach to study development of opioid tolerance. Although the low levels of spontaneous opioid secretion by these cell implants did not change the baseline tail flick and hot plate latencies, these levels may still be sufficient to produce tolerance. This is supported by the observation that continual intrathecal infusion in rat of low doses of morphine produced opioid tolerance (Stevens and Yaksh, 1989a,b). Continual intrathecal infusion of $\beta$-endorphin in primate spinal cord produces tolerance to $\beta$-endorphin (Yaksh et al., 1982). As expected, mice receiving AtT20 cell implants exhibited tolerance to $\beta$-endorphin. In addition, they developed tolerance to the $\mu$-opioid receptor agonist DAMGO. These results support the hypothesis that the implanted cells tonically released $\beta$-endorphin. The present study also showed that mice receiving AtT-20/hENK cell implants, but not mice receiving AtT-20 cell implants, exhibited tolerance to the $\delta$-opioid receptor agonist DPDPE. This confirms that implanted At T-20/hENK cells tonically released enkephalin. However, mice receiving genetically modified AtT-20/hENK cell implants did not develop tolerance to $\beta$-endorphin or DAMGO. One possible interpretation of this result is that these genetically modified cells do not release $\beta$-endorphin. However, the observation that the antinociception induced by isoproterenol in At T-20/hENK cell-implanted mice was not blocked by $\delta$-opioid antagonist alone, but required the presence of $\delta$ - and $\mu$-opioid receptor antagonists, suggests that this antinociception was mediated partly through $\beta$-endorphin. The lack of $\beta$-endorphin tolerance might indicate that co-released enkephalin from AtT$20 /$ hENK cell implants somehow modulated the development of $\beta$-endorphin tolerance.

AtT-20/hENK cell implants, but not AtT-20 cell implants, also reduced the development of acute morphine tolerance. Since the primary difference between these two cell types is that AtT20/hENK cells, but not AtT-20 cells, secrete enkephalins, it is reasonable to suggest that enkephalins were responsible for modulation of morphine tolerance with the AtT-20/hENK cell implants. A previous study showed that morphine tolerance can be attenuated by chronic administration of met-enkephalin (Graf et al., 1979), although there is evidence that conflicts with this finding (Lee et al., 1980). Differences in the administration of enkephalins may account for these differing results. Chronic administration of enkephalin, such as that which might occur with implantation of enkephalin-secreting cells, may be critical for modulation of morphine tolerance by enkephalin. It has been reported that blockade of $\delta$-opioid receptors prevents the development of morphine tolerance in mice (Abdelhamid et al., 1991), while upregulation of $\delta$-opioid receptor binding sitcs accompanies the development of morphine tolerance in mice (Abdelhamid and Takemori, 1991). The present study showed that mice receiving AtT $-20 / \mathrm{hENK}$ cell implants developed tolerance at $\delta$-opioid receptors. This downregulation of $\delta$-opioid receptors may have similar effects on the development of morphine tolerance to those that accompany selective blockade of $\delta$-opioid receptors (Abdelhamid et al., 1991).

Whether an opioid agonist produces tolerance only at a particular receptor subtype, or at another receptor subtype as well, is still controversial (Yaksh, 1983; Russel et al., 1987). The 
present study showed that animals receiving AtT-20 cell implants, which tonically release $\beta$-endorphin only, exhibited tolerance at $\mu$-opioid receptors, but not at $\delta$-opioid receptors. This is contrary to a previous observation that continual intrathecal infusion of a selective $\mu$-opioid receptor agonist produced tolerance at both $\mu$ - and $\delta$-opioid receptors (Russel et al., 1987). Differences between the synthetic opioid agonist used in the previous study and the biological opioid peptide secreted by the cell implants in the present study may account for this difference. It has been suggested that the biological properties of synthetic peptide analogs are often altered and unable to mimic the endogenous ligands exactly (Akil et al., 1988). Opioid-secreting cell implants serve as a source of biological ligands for the study of tolerance induction by naturally occurring opioid peptide.

This study identified and pharmacologically characterized an antinociceptive effect resulting from opioid-producing AtT-20 and genetically modified At T-20/hENK cells implanted around mouse spinal cord. Cell implants releasing analgesic substances may provide a practical approach to the clinical control of chronic intractable pain. Issues related to tumorigenesis and metastasis of these cancer cell lines need to be further investigated to determine the feasibility of this approach in a clinical setting. The finding that genetically modified AtT-20/hENK cell implants prevented morphine tolerance suggests that chronic administration of enkephalins along with morphine might benefit patients with chronic intractable pain who have developed tolerance to morphine. AtT-20 and genetically modified AtT-20/ hENK cell implants also provide a useful model to study the biological properties of $\beta$-endorphin and enkephalins, and the interaction between these two endogenous opioids.

\section{References}

Abdelhamid EE, Takemori AE (1991) Characteristics of mu and delta opioid binding sites in striatal slices of morphine-tolerant and -dependent mice. Eur J Pharmacol 198:157-163.

Abdelhamid EE, Sultana M, Portoghese PS, Takemori AE (1991) Selective blockage of delta opioid receptors prevents the development of morphine tolerance and dependence in mice. J Pharmacol Exp Ther 258:299-303.

Akil H, Bronstein D, Mansour A (1988) Overview of the endogenous opioid systems: anatomical, biochemical and functional issues. In: Endorphins, opiates and behavioural processes (Rodgers R.I, Cooper SJ, eds), pp 1-23. New York: Wiley.

Allen RG, Herbert E, Hinman M, Shibuya H, Pert CB (1978) Coordinate control of corticotropin, $\beta$-lipotropin, and $\beta$-endorphin release in mouse pituitary cell cultures. Proc Natl Acad Sci USA 75:49724976.

Axelıod J, Reisine TD (1984) Stress hormones: their interaction and regulation. Science 224:452-459.

Bonica JJ (1990) History of pain concepts and therapies. In: The management of pain (Bonica JJ, ed), pp 2-17. Philadelphia: Lea \& Febiger.

Buonassisi V, Sato G, Cohen AI (1962) Hormone-producing cultures of adrenal and pituitary tumor origin. Biochemistry 48:1184-1190.

Chapman DB,.Hu J, Way EL (1980) Methionine-enkephalin antagonism and endorphin potentiation of narcotic-induced analgesia. Eur J Pharmacol 65:369-377.

Comb M, Liston D, Martin M, Rosen H, Herbert E (1985) Expression of the human proenkephalin gene in mouse pituitary cells: accurate and efficient mRNA production and proteolytic processing. EMBO J $4: 3115-3122$.

Coombs DW (1988) Intraspinal analgesic infusion by implanted pump. Ann NY Acad Sci 531:108-122.

Graf L, Miglecz E, Bajusz S, Szekely JI (1979) Met-enkephalin attenuates morphine tolerance in rats. Eur J Pharmacol 58:345-346.

Hama AT, Sagen J (1993) Reduced pain-related behavior by adrenal medullary transplants in rats with experimental painful peripheral neuropathy. Pain 52:223-231.
Hassenbusch SJ, Pillay PK, Magdinec M, Currie K, Bay JW, Covington EC, Tomaszewski MZ (1990) Constant infusion of morphine for intractable cancer pain using an implanted pump. J Neurosurg 73: 405-409.

Heyman JS, Vaught JL, Mosberg HI, Haaseth R, Porreca F (1989) Modulation of mu-mediated antinociception by delta agonists in the mouse: selective potentiation of morphine and normorphine by [DPen², D-Pen ${ }^{5}$ ]enkephalin. Eur J Pharmacol 165:1-10.

Hook VYH, Heisler S, Sabol SL, Axelrod J (1982) Corticotropin releasing factor stimulates adrenocorticotropin and $\beta$-endorphin release from AtT-20 mouse pituitary tumor cells. Biochem Biophys Res Commun 106:1364-1371.

Hylden JL, Wilcox GL (1980) Intrathecal morphine in mice: a ncw technique. Eur J Pharmacol 67:313-316.

Hylden JLK, Wilcox GL (1983) Pharmacologic characterization of substance P-induced nociception in mice: modulation by opioid and noradrenergic agonists at the spinal level. J Pharmacol Exp Ther 226: 398-403.

Janssen PAJ, Niemgeers CJE, Dorg JGH (1963) The inhibitory effects of fentanyl and other morphine-like analgesics on the warm water induced tail withdrawal reflex in rats. Arzneim Forsch 13:502-507.

Jiang Q, Mosberg HI, Porreca F (1990) Modulation of potency and efficacy of mu-mediated antinociception by delta agonists in the mouse. J Pharmacol Exp Ther 254:683-689.

Laugner B, Muller A, Thiebaut J, Farcot J (1985) Analgesia with an implanted device for repetitive intrathecal injections of morphine. Ann Fr Anesth Reanim 4:511-520.

Lee NM, Leybin L, Chang JK, Loh HH (1980) Opiate and peptide interaction: effect of enkephalins on morphine analgesia. Eur J Pharmacol 68:181-185.

Micevych P, Elde RP (1980) Relationship between enkephalinergic neurons and the vasopressin-oxytocin neuroendocrine system of cat: an immunohistochemical study. J Comp Neurol 190:135-146.

Nagasaka H, Yaksh TL (1990) Pharmacology of intrathecal adrenergic agonists: cardiovascular and nociceptive reflexes in halothane-anesthetized rats. Anesthesiology 73:1 198-1207.

Onofrio BM, Yaksh TL (1990) Long-term pain relief produced by intrathecal morphine infusion in 53 patients. J Neurosurg 72:200209.

Oyama T, Jin T, Yamaya R, Ling N, Guillemin R (1980) Profound analgesic effects of $\beta$-endorphin in man. Lancet 1:122-124.

Plummer JL, Cherry DA, Cousins MJ, Gourlay GK, Onley MM, Evans KHA (1991) Long-term spinal administration of morphine in cancer and non-cancer pain: a retrospective study. Pain 44:215-220.

Reisine TD, Heisler S, Hook VYH, Axelrod J (1983) Activation of $\beta_{2}$-adrenergic receptors on mouse anterior pituitary tumor cells increases cyclic adenosine $3^{\prime}: 5^{\prime}$-monophosphate synthesis and adrenocorticotropin release. J Neurosci 3:725-732.

Russell RD, Leslie JB, Su Y-F, Watkins WD, Chang K-J (1987) Continuous intrathecal opioid analgesia: tolerance and cross-tolerance of mu and delta spinal opioid receptors. J Pharmacol Exp Ther 240: $150-158$.

Sagen J, Kemmler JE (1989) Increased levels of met-enkephalin-like immunoreactivity in the spinal cord CSF of rats with adrenal medullary transplants. Brain Res 502:1-10.

Sagen J, Pappas GD (1987) Morphological and functional correlates of chromaffin cell transplants in CNS pain modulatory regions. Ann NY Acad Sci 495:306-333.

Sagen J, Wang H, Pappas GD (1990) Adrenal medullary implants in the rat spinal cord reduce nociception in a chronic pain model. Pain 42:69-79.

Sagen J, Kemmler JE, Wang H (1991a) Adrenal medullary implants increase spinal cord cerebrospinal fluid catecholamine levels and reduce pain sensitivity. J Neurochem 56:623-627.

Sagen J, Winnie AP, Wang H, Krolick TJ, Pappas GD (1991b) Pain reduction by adrenal medullary transplants in the spinal subarachnoid space of terminal cancer patients. Soc Neurosci Abstr 17:235.

Schwabe U, Miyake M, Ohga Y, Daly JW (1976) 4-(3-Cyclopentyloxy4-methoxyphenyl)-2-pyrrolidinc (ZK 62711): a potent inhibitor of adenosine cyclic 3',5'-monophosphate phosphodiesterases in homogenates and tissue slices from rat brain. Mol Pharmacol 12:900-910.

Stevens CM, Yaksh TL (1989a) Potency of infused spinal antinociceptive agents is inversely related to magnitude of tolerance after continuous infusion. J Pharmacol Exp Ther 250:1-8.

Stevens CM, Yaksh TL (1989b) Magnitude of opioid dependence after 
continuous intrathecal infusion of $\mu$ - and $\delta$-selective opioids in the rat. Eur J Pharmacol 166:467-472.

Suh HH, Tseng L-f (1988) Intrathecal $\beta$-funaltrexamine antagonizes intracerebroventricular $\beta$-endorphin- but not morphine-induced analgesia in mice. $\mathbf{J}$ Pharmacol Exp Ther 245:587-593.

Suh HH, Tseng LF (1990) Delta but not mu-opioid receptors in the spinal cord are involved in antinociception induced by $\beta$-endorphin given intracerebroventricularly in mice. J Pharmacol Exp Ther 253: 981-986.

Tallarida RJ, Murray RB (1987) Manual of pharmacologic calculations with computer programs. New York: Springer.

Vaught JL, Takemori AE (1979) Differential effects of leucine and methionine enkephalin on morphine-induced analgesia, acute tolerance and dependence. J Pharmacol Exp Ther 208:86-90.

Wen HL, Mehal ZD, Ong BH, Ho WKK, Wen DYK (1985) Intrathecal administration of beta-endorphin and dynorphin-(1-13) for the treatment of intractable pain. Life Sci 37:1213-1220.

Wilcox GL (1988) Pharmacological studies of grooming and scratching behavior elicited by spinal substance $P$ and excitatory amino acids. Ann NY Acad Sci 525:228-236.

Woolfe G, MacDonald AD (1944) The evaluation of the analgesic action of pethidine hydrochloride (Demerol). J Pharmacol Exp Ther 80:300-307.
Wu H, McLoon SC, Wilcox GL (1992) Spinal implants of cells genetically modified to produce enkephalin reduce nociceptive sensitivity in host mice. Soc Neurosci Abstr 18:781.

Yaksh TL (1981) Spinal opiate analgesia: characteristics and principles of action. Pain 11:293-346.

Yaksh TL (1983) In vivo studies on spinal opiate receptor systems mediating antinociception. I. Mu and delta receptor profiles in the primate. J Pharmacol Exp Ther 226:303-316.

Yaksh TL (1985) Pharmacology of spinal adrenergic systems which modulate spinal nociceptive processing. Pharmacol Biochem Behav 22:845-858.

Yaksh TL, Henry JL (1978) Antinociceptive effects of intrathecally administered human $\beta$-endorphin in the rat and cat. Can J Physiol Pharmacol 56:754-756.

Yaksh TL, Noueihed R (1985) The physiology and pharmacology of spinal opiates. Annu Rev Pharmacol Toxicol 25:433-462.

Yaksh TL, Huang SP, Rudy TA (1977) The direct and specific opiatelike effect of met $^{5}$-enkephalin and analogues on the spinal cord. Neuroscience 2:593-596.

Yaksh TL, Gross KE, Li CH (1982) Studies on the intrathecal effect of beta-endorphin in primate. Brain Res 241:261-269. 